\title{
結核性肩峰下滑液包炎の一症例
}

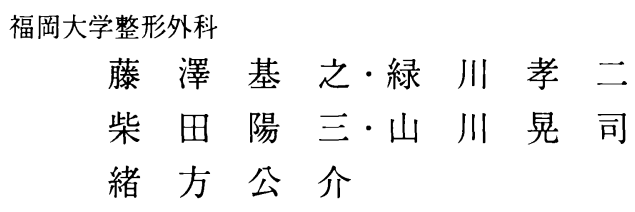

\section{A Case Report of Tuberculosis of the Subacromial Bursa}

\author{
by
}

\author{
Motoyuki Fujisawa, Koji Midorikawa, Yozo Shibata, \\ Koji Yamakawa and Kosuke Ogata
}

Department of Orthopaedic Surgery, School of Medicine, Fukuoka University, Fukuoka, Japan

\begin{abstract}
A sixty-year-old man was seen complaining of discomfort and swelling without pain in his left shoulder. On examination slight restriction of motion was found, but the muscle strength of left upper extremity was within normal limits. The only positive result from the laboratory studies was elevation of the level of rheumatoid factor. Tuberculin test was found to be strongly positive. Thickening of the wall of subacromial bursa and a large number of rice bodies suspended in the fluid were observed by echo gram, MRI and bursography.

The subacromial bursa was resected surgically. After the operation, medical treatment for tuberculosis was started. Symptoms and abnormal data recovered to normal six months after operation. Pathological study of the tissue showed granuloma with caseous necrosis and multi-uncleated giant cells. Tuberculous bacteria was detected from the cultivation of the tissue. The diagnosis of tuberculosis of the subacromial bursa was thus confiremed.

We suggest that early surgical treatment is necessary to avoid invasion of the infected lesion to surrounding tissues.
\end{abstract}

Key words : Subacromial Bursa (肩峰下滑液包), Rice Body (米粒体), Tuberculosis（結核）

\section{はじめに}

整形外科領域における結核において，骨関節での発 生は，抗結核剤の発達した今日でも散見される。しか し肩峰下滑液包に限局して結核が発症し, 骨関節に及 んでいない症例は極めて稀である.

今回我々は, 結核性肩峰下滑液包炎の確定診断と良 好な結果を得た症例を経験したので報告する.

症 例

\section{主訴 : 左肩の腫脹と異和感}

現病歴 : ’94 年 12 月誘因なく主訴が出現。'95 年 1 月某医受診し, 滑液包水腫に対し数回の穿刺吸引, ス テロイド注入を受けたが, 症状改善せず，'96 年 8 月 当科紹介受診した。

既往歴: 17 歳時, 左側の肺結核に罹患し, 約 6 ケ 月間内服薬による治療を受けた。

現症 : 左肩関節周囲の波動と腫脹を認めたが, 自覚 症状として, 疼痛なく異和感を訴えるのみであった。 他覚的には, 可動域に若干の左右差を認めたが, 肩甲 帯及び上肢の筋力低下や神経学的異常は認めなかった

60 歳 男性 会社員 
(Fig. 1).

血液所見 : WBC : 4000, CRP : 0.1 (-), ESR : $4 / 22, \mathrm{RF}: 22(+)$ で, リウマチ因子以外の異常所 見はなかった。

ッベルクリン反応 : 発赤の長径が $25 \mathrm{~mm}$ で硬結を 伴っており，強陽性であった。

画像所見：胸写上，結核の既往によると思われる， 左肺野の縮小と石灰化陰影を認めた。肩関節単純写で は，異常所見は認めなかった（Fig. 2).

超音波検查では，滑液包内に液体の貯留と high echo の粒状陰影を認め, 滑液包壁の肥厚も認めた. MRIでも，超音波と同様の所見が認められた（Fig， $3)$.

また，肩峰下滑液包造影では，滑液包内に多量の粒 状陰影が認められ，米粒体の存在を示唆した (Fig. 4).

結核の既往, ツベルクリン反応強陽性, 多量の米粒 体を疑わせる画像所見より, 結核性肩峰下滑液包炎を 強く疑い，観血的手術を施行した。

手術所見: 三角筋を肩峰より骨膜とともに剥離し線 維方向に分け滑液包に至る，滑液包に切開を加えると， 黄色の混濁した液体と共に多量の米粒体の流出を認め た．局甲上腕関節内への感染の波及を危惧し，肩峰下
滑液包全切除を施行した，滑液包は正常の解剖学的位 置を越え，前後下方へ著明に拡大しており，滑液包壁 は一様に硬化肥厚していた（Fig. 5). 滑液包切除後, 腱板には硬化や肥厚は認めず肉眼的には腱板への波及 はないと判断した。

病理：摘出組織の HE 染色の鏡検では，弱拡で乾 酪性壊死を伴う肉芽組織を認め, 強拡でラングハンス 型巨細胞を認め, 結核菌感染が疑われた（Fig. 6)。

培養：小川培地を用いた $37^{\circ} \mathrm{C}$ 培養では菌発育が認 められ，結核菌陽性と判定された。しかし，非定型抗 酸菌感染を示す $25 \sim 32^{\circ} \mathrm{C}$ の低温培養では菌発育が陰 性で，結核菌感染の確定診断を得た。

術後療法: 翌日より, 他動的可動域改善訓練からリ ハビリテーションを開始した，並行して，培養結果を 待たず早期にイソニアジド，リファンピシン，エタン ブトールを用いた抗結核郕の内服を開始した。エタン ブトールによる視力障害が出現したため投与量は減量 したが，抗結核剤の投与を術後 6 ケ月まで続行し，疼 痛なく, 可動域制限も認めていない。この間，内科医 の診療を受けているが, 胸写や血液検査での変化はな く, 術後 6 ケ月で抗結核剤投与を終了した。

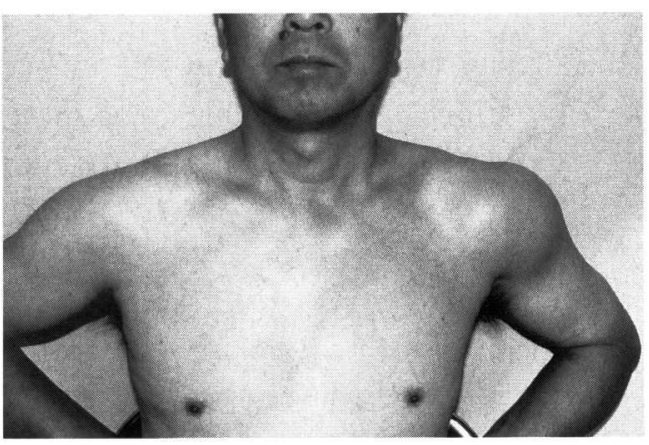

A

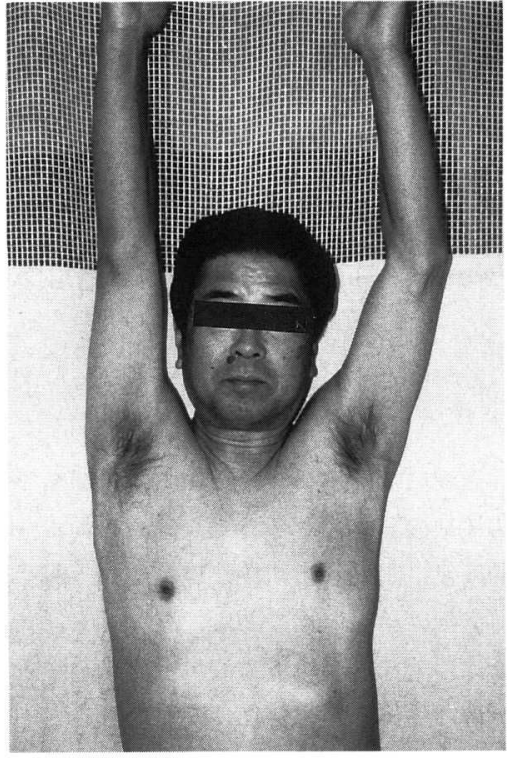

B

Fig. 1 A : 左肩関節周囲の波動と腫脹を認めた B : 可動域は若干の左右差を認めた. 


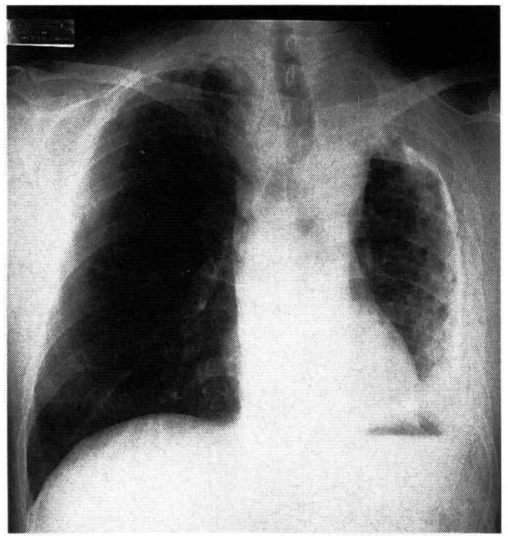

A

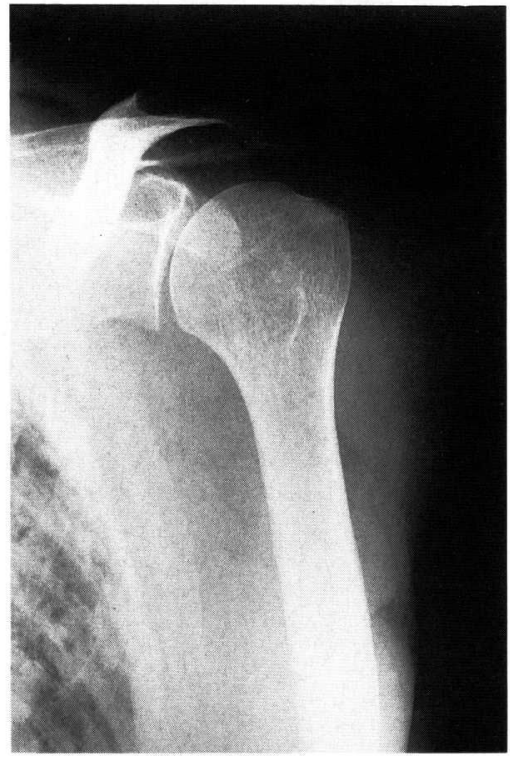

B

Fig. 2 A : 胸写上, 結核の既往による左肺野の縮小と石灰化陰影を認める

$\mathrm{B}$ : 肩関節単純写では, 異常所見は認めない.

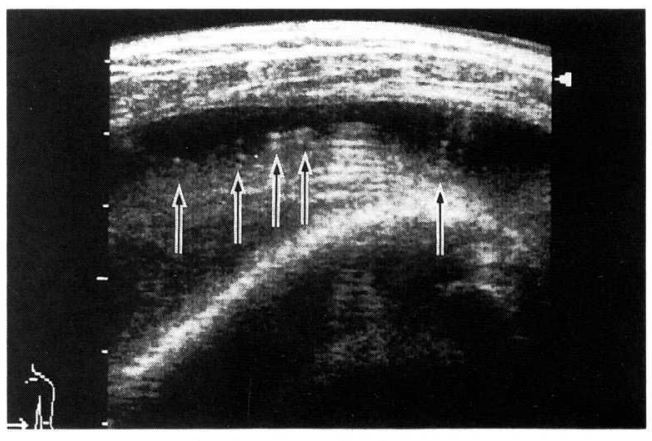

A

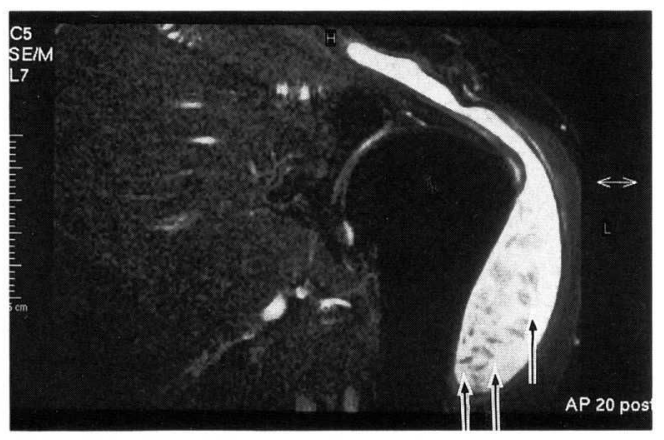

B

Fig. 3 A : 超音波検査では, 滑液包壁の肥厚と滑液包内に液体の貯留, その内部に high echoの粒状陰影（ヤ）を認める.

B：MRI でも，超音波と同様の所見が認められる. 

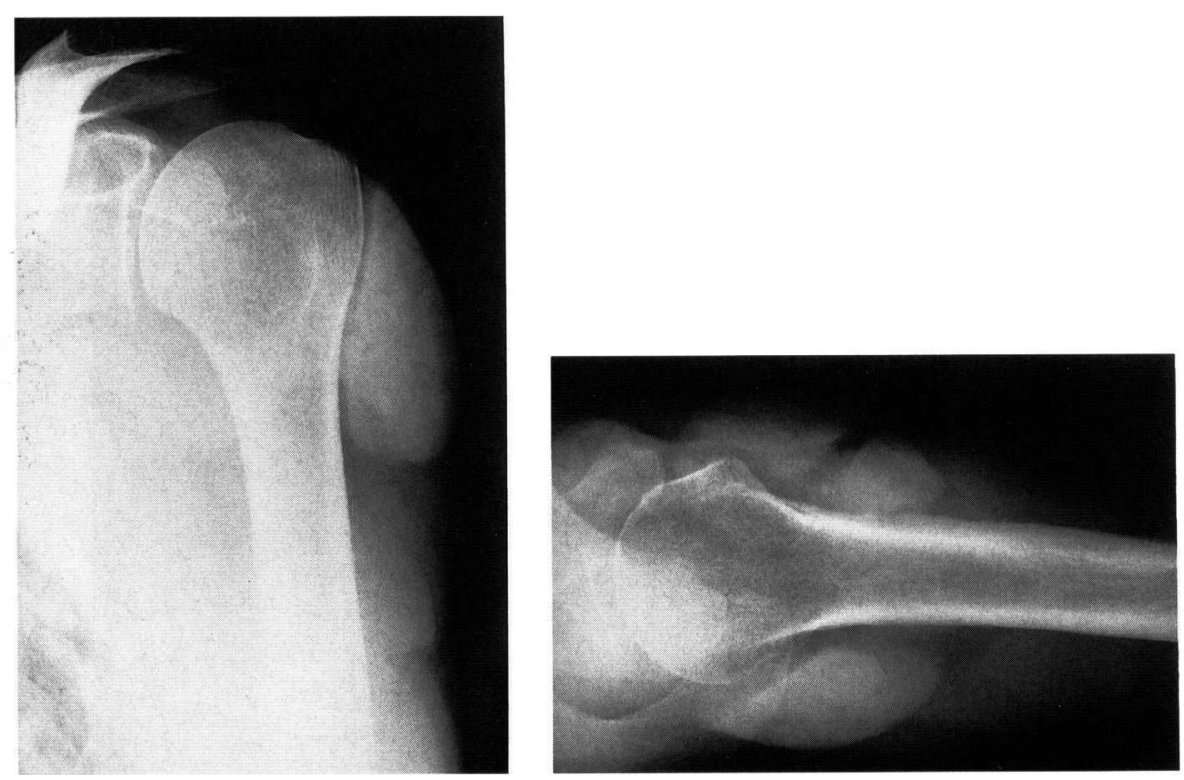

Fig. 4 肩峰下滑液包造影では, 滑液包内に多量の粒状陰影が認められる.

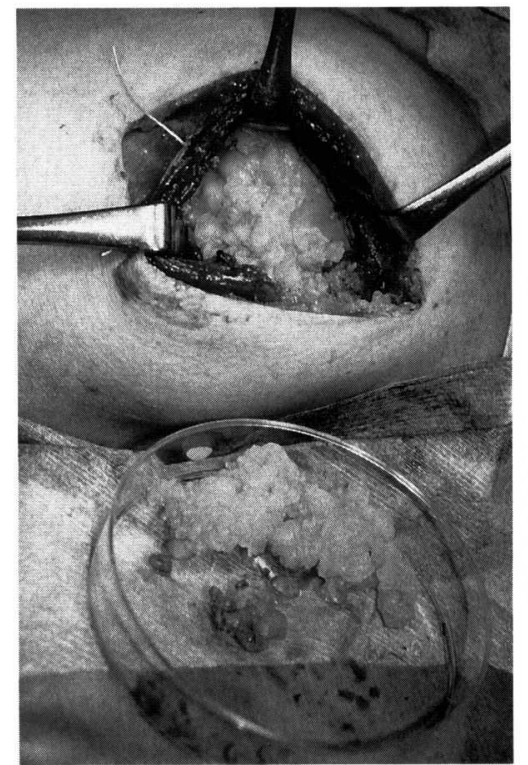

A

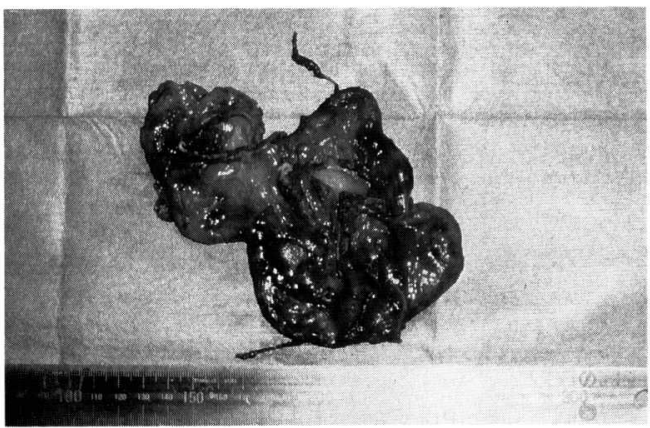

B

Fig. 5 A : 滑液包に切開を加えると, 黄色の混濁した液体と共に多量の米粒体の流出を 認めた.

B : 滑液包の著明な拡大と, 滑液包壁の硬化肥厚を認める. 


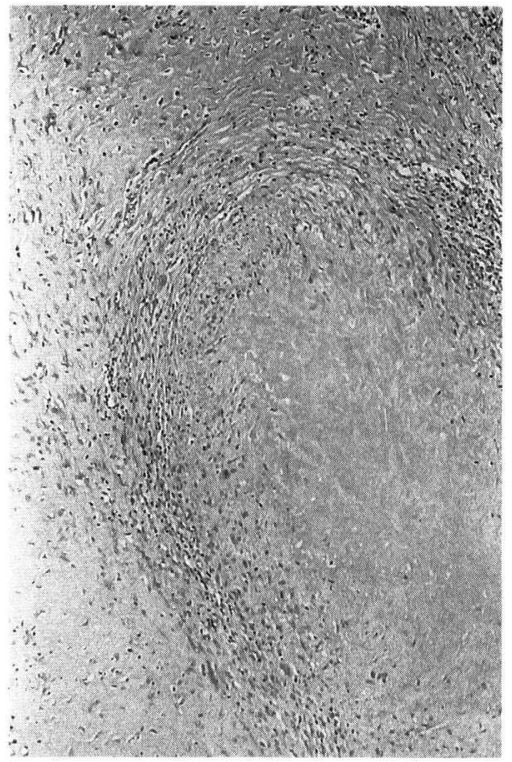

A

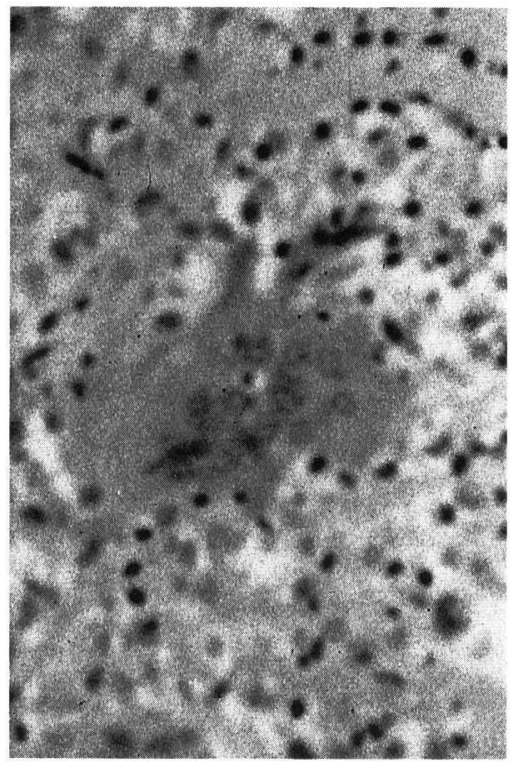

B

Fig. $6 \mathrm{~A}$ : 弱拡で乾酪性壊死を伴う肉芽組織を認める. B : 強拡でラングハンス型巨細胞を認める.

\section{考}

察

整形外科領域における結核において骨関節での発生 は, 全結核患者のうち約 $1.2 \%^{8)}$ で, 抗結核剤の発達 により肺結核の激隇した今日でも散見される。この中 でも，肩峰下滑液包に限局した症例の報告は極めて少 ない，肩関節においては，肩甲上腕関節における結核 は骨関節結核の $2.0 \%$ ”) と散見されるが, 肩峰下滑液 包に限局した結核の報告は, 1911 年 $\mathrm{Cone}^{1)}$ の 1 例, Deacon $^{2)}$ の 1 例, Etchegorry と Blanco ${ }^{3)} の 1$ 例, $\operatorname{Pimm}^{10}$ の 2 例, Kenin ${ }^{6)}$ の 3 例, Suphaneewan ${ }^{11)}$

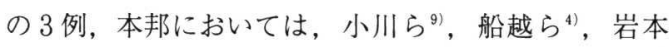
$ら^{5)}$, 山口ら ${ }^{13)} の$, それぞれ 1 例, 計 4 例の報告を涉 猟しえたのみである。

診断に関しては, これらの報告において, ッベルク リン反応や, 滑液包内の米粒体（遊離体），ラングハ ンス巨細胞や乾酪壊死が認められる病理所見などを根 拠になされている．今回の症例も，既往歴やこれらの 所見により, 結核菌感染を強く疑い, 観血的手術を施 行した. しかし, Mycobacterium marinum を中 心とする非定型抗酸菌感染は, 結核菌感染と類似した
病理組織像を示すため, 組織学的には鑑別が困難であ るとされている ${ }^{12)}$. 肩峰下滑液包の結核菌感染が疑わ れた場合，結核菌培養の結果を待たず，抗結核剤の投 与を早期に開始しなければならないが, 非定型抗酸菌 感染の有無についての評価するため, 手術時に得られ た検体の培養も必要であると考えられた. 今回我々は, 手術時に得られた組織の小川培地を用いた培養結果で, $25 \sim 32^{\circ} \mathrm{C}$ の低温培養では菌発育が陰性であったが, $37^{\circ} \mathrm{C}$ 培養では菌発育を認め, 非定型抗酸菌感染を鑑 別し結核菌感染の確定診断を得た。

また, 今回の症例では施行していないが, 結核菌の 同定を目的としたPCR 法) (Polymerase Chain Reaction）が最近注目されている.この方法はごく 少量の結核菌に特有な DNA を増幅させ, 結核菌 DNA を同定する方法で, 数時間内にDNAを 100 万 倍に増幅させることができるとされている，様々の検 体から直接結核菌の同定が可能であり, 今回のような 症例にも今後適用すべきだと考えられる.

一方, 米粒状の鑑別診断としては, 結核・慢性関節 リウマチなどの炎症性疾患, 滑膜性骨軟骨腫症などが ある。今回の症例では, リウマチ因子が陽性であった 
が, 慢性関節リウマチの臨床症状はなかったが, 臨床 症状と病理組織学的検索により鑑別する必要がある。

$$
\text { ま と め }
$$

(1)滑液包に限局した結核病変を認め, 骨関節への波 及を危惧し，早期に滑液包切除と抗結核療法を施行し， 良好な結果を得た。

(2)術中得られた組織の病理組織検査に加え，結核菌 培養を施行し, 確定診断を得た。

\section{参 考 文 献}

1) Apfelbuch, G.: 1: Bursitis, Indust. Med and Surg. $19: 475,1950$.

2) Deacon, A.E.: Tuberculosis bursitis of both subdeltoid bursae, proc. Staff Meeting of Mayo Clinic., $10: 175,1935$.

3) Etchegorry, F., Blanco, R.P.: Bursitis Supurada Subdeltoideana, de Posible Origen Tuberculoso. Archivos Urguayos de Medicine, Cirugiay Especiaridades, $20: 349-357,1942$.
4）船越正男ほか：結核性三角筋下滑液包炎と結核性橈側 手根屈筋腱鞘炎の合併した 1 症例. 北海道整災誌, 11 : 222,1966 .

5）岩本英明ほか：結核性滑液包炎の 1 症例。整形外科と 災害外科，35(3)：994-997, 1987.

6) Kenin, A.: Tuberculosis of Subdeltoid Bursa. Bulletin of the Hospital for Joint Desease, $7: 28,1946$.

7）百町国彦ほか：国立療養所における肺外結核の実態と 化学療法. 結核, $61: 399-412,1986$.

8）野々村昭孝ほか：骨関節結核。新図説臨床整形外科講 座, vol. 12 感染症 : 236-254, 1995.

9）小川清久ほか: 肩関節腱板損傷を疑わせた結核性肩峰 下滑液包炎の 1 例。臨整外, 9 巻 $5: 442,1974$.

10) Pimm, L. H.: Tuberculosis of the Subdertoid Bursa JBJS, 37-B : 102, 1955.

11) Suphaneewan, Jaovidha: Tuberculous Tenosynovitis and Bursitis: Imaging Findings in 21 Caces. Radiology 201-2 Nov. 1996.

12）鳥巣岳彦; 細菌学的検査. 関節外科, vol. 8 no. 5 : 7782,1989

13）山口鉄生ほか：肩関節における滑液包内遊離体の 2 例. 整形外科上災害外科, 46(1)：19-23，1997. 